\title{
Experiencing organizational change during an era of reform: Police Scotland, narratives of localism, and perceptions from the 'frontline'.
}

FYFE, N.R., ANDERSON, S., BLAND, N., GOULDING, A., MITCHELL, J. and REID, S.

This is a pre-copyedited, author-produced version of an article accepted for publication in Policing following peer review. The version of record FYFE, N.R., ANDERSON, S., BLAND, N., GOULDING, A., MITCHELL, J. and REID, S. 2021. Experiencing organizational change during an era of reform: Police Scotland, narratives of localism, and perceptions from the 'frontline'. Policing, 15(1), pages 263-276 is available online at: https://doi.org/10.1093/police/pay052.

(C) The Author(s) 2018. Published by Oxford University Press. All rights reserved. For permissions please e-mail: journals.permissions@oup.com 
Experiencing organisational change during an era of reform:

Police Scotland, narratives of localism and perceptions from the 'frontline'

Nicholas R. Fyfe (Scottish Institute for Policing Research and School of Social Sciences, University of Dundee, Dundee, DD1 4HN)

Simon Anderson (Scottish Institute for Policing Research, School of Social Sciences, University of Dundee, DD1 4HN)

Nick Bland (What Works Scotland, University of Edinburgh

Room 3.04 Chrystal Macmillan Building, 15a George Square, Edinburgh EH8 9LD

Amy Goulding (Scottish Institute for Policing Research and School of Social Sciences, University of Dundee, Dundee, DD1 4HN)

James Mitchell (What Works Scotland, University of Edinburgh

Room 3.04 Chrystal Macmillan Building, 15a George Square, Edinburgh EH8 9LD

Susan Reid (ScotCen Social Research, Scotiabank House, 6 South Charlotte Street,

Edinburgh EH2 4AW)

Corresponding author:

Nicholas R. Fyfe (n.r.fyfe@dundee.ac.uk)

Word Count: 7171

This is a pre-copyedited, author-produced version of an article accepted for publication in Policing: A Journal of Policy and Practice following peer review. The version of record Fyfe, N. R., Anderson, S., Bland, N., Goulding, A., Mitchell, J., \& Reid, S. 'Experiencing Organizational Change During an Era of Reform: Police Scotland, Narratives of Localism, and Perceptions from the 'Frontline', Policing: A Journal of Policy and Practice (2018) is available online at: https://academic.oup.com/policing/ and https://doi.org/10.1093/police/pay052 


\section{Introduction}

In his reflections on major police reforms in the United States, David Bayley (2008: 7) observed that these are almost always driven by external forces, are top-down, and rarely involve consultation with rank-andfile officers. Such observations closely resonate with aspects of the recent experience of police reform in Scotland discussed in this paper. The 'external forces' of the financial crisis of 2007-08, and the resulting pressure on public spending, led the Scottish Government's Justice Secretary to announce in 2010 the need to identify a 'sustainable policing model' for Scotland. The outcome of this process, involving senior government officials and senior police officers, was the decision in 2011 to create a single, national police force, reconfiguring a structure of regional police forces which had prevailed since the $19^{\text {th }}$ century. Mergers and amalgamations of local forces in Scotland was, of course not new. From more than 90 forces in the 1850s, there were just 8 on the eve of reform. Nevertheless, the existence of separate forces still enshrined a principle that police forces were local services, formally accountable to boards of locally elected councillors and partly funded by local taxation. The creation of Police Scotland therefore marked a radical break with the past and one which quickly polarized opinion. Supporters of the reform declared it represented the logical outcome of an historical process of rationalization creating larger forces and provided the opportunity to develop a more effective and efficient approach to policing in a time of austerity, with expected saving of over $£ 100$ million a year (or $10 \%$ of the police budget without the need to reduce officer numbers). Rejecting arguments for retaining 8 'local' forces (which ranged in size from Strathclyde Police with over 8000 officers covering 8 local authority areas and over 2.5 million people, to Dumfries and Galloway Constabulary in the rural southwest of Scotland with just 500 officers responsible for a single local authority area of less than 150,000 people) and the duplication of administrative arrangements this entails, the Scottish Government declared that 'Communities don't care about boundaries; they want services to work effectively and efficiently' (Scottish Government, 2011a). For critics, a national police force represented the nationalization of a local government service, fears that it 
would lead to a 'one size fits all' approach to policing and concerns that it would draw resources away from more rural and remote areas, concentrating them in the main urban areas. There were also political anxieties that it would lead to greater interference in policing through too close a relationship between Government ministers and the Chief Constable (Scottish Government, 2011b).

These differing views about the implication of reform for local policing have continued to play a central role in the debates about the creation of a single police service since it became operational in 2013 . In this paper, however, we explore the experience of organizational change in Scotland following police reform from the perspectives of local officers and local communities. Drawing on research carried out in 4 communities across Scotland in 2016 (SIPR et al, 2017) the analysis is structured around the Scottish Government's three strategic aims for reform - of improved service delivery, more equal access to specialist expertise, and enhanced connections with communities - but in addition the paper explores (echoing Bayley) the sense of exclusion from the decision-making surrounding the organizational changes associated the implementation of reform experienced by local, rank-and-file officers. To put this analysis in context, however, the first two sections of the paper explore the 'contours of reform', focusing on the narratives of localism set out in the legislation that established Police Scotland, and the 'conflicts of reform' and an emerging crisis of localism which rapidly developed in the two years after the start of the national force.

\section{The contours of reform and narratives of localism}

The 2012 Police and Fire Reform (Scotland) Act set out 3 major changes to policing in Scotland (see too Fyfe, 2014; Fyfe and Scott, 2013). First, it merged the 8 regional police forces to create a national police force under the direction and control of a chief constable with responsibility for the administration, allocation and deployment of resources and the provision of information. Second, it replaced the locally elected police authorities and replaced these with an unelected national body, the Scottish Police 
Authority (SPA), with responsibility for resourcing the police service, supporting continuous improvement, and holding the chief constable to account. Third, the Act made 'local policing' a statutory requirement at the level of the 32 council areas. Although local policing is not specifically defined in the legislation and has therefore become a highly contested area, the Act requires the chief constable to nominate an identified local commander responsible for preparing a local policing plan in consultation with the local authority. The local authority must also establish arrangements for the scrutiny of local policing, but the Act does not prescribe what form this scrutiny should take (see Henry, Malik, and Aitchison, 2016a and 2016b). Underpinning this commitment to localism, the Act sets out a normative vision for policing in the form of a set of 'principles' which offer a narrative of local policing based on partnership working, community well-being and harm reduction:

the main purpose of policing is to improve the safety and well-being of persons, localities and communities in Scotland, and that the Police Service, working in collaboration with others where appropriate, should seek to achieve that main purpose by policing in a way which (i) is accessible to, and engaged with, local communities, and (ii) promotes measures to prevent crime, harm and disorder' (Police and Fire Reform (Scotland) Act, 2012, para.32).

In addition to these key elements of the legislation, the Scottish Government also articulated three strategic aims for its reform of policing which reinforce this commitment to localism. First, the reform aims to 'protect and improve local services despite financial cuts, by stopping duplication of support services eight times over and not cutting front line services'; second, the reform should create more equal local access to specialist support and national capacity 'where and when they are needed', so ending the uneven availability of resources which characterised the old regional policing arrangements; third, the reform should 'strengthen the connection between services and the communities they serve by providing an opportunity for more local councillors to be involved in shaping local services' through the local scrutiny arrangements which are referred to in the legislation (see above). 


\section{The conflicts of reform and a crisis of localism?}

The strong narrative of localism which weaves its way through the legislation and aims of police reform in Scotland, stands in stark contrast with the reality of the implementation of reform (see too Terpstra and Fyfe, 2015). Concerns quickly emerged about both the structure and style of local policing within Police Scotland. In terms of structure, the Chief Constable implemented arrangements for local policing that differ in important respects from those set out in the original legislation (Terpstra and Fyfe, 2015). Although there are 32 local police areas aligned with the boundaries of local authorities each with a local commander as required by the Scottish Police Reform Act, the main territorial and administrative units for local policing are 17 police divisions (subsequently reduced to 14 due to local mergers). In three areas the boundaries of these divisions are aligned with those of a single local authority but most divisions comprise several local authority areas. While this structure for delivering local policing offers a degree of managerial efficiency as well as robustness in terms of the scale of resource available within each division, from a local authority perspective, this configuration creates a more complex landscape. For the local authorities who have boundaries co-terminus with the police divisions, there is a direct link with a divisional commander of the rank of Chief Superintendent. In the majority of local authority areas, however, the most senior officer will typically be of a lower rank with less power and autonomy, creating a more differentiated landscape within which local authorities must interact with the police from that set out in the original legislation.

In terms of the style of local policing, concerns rapidly emerged after the establishment of Police Scotland of a shift away from local community engagement and partnership working and towards a more enforcement focused approach (Fyfe, 2016). This shifting 'culture of control' was exemplified in June 2013, a little over two months after Police Scotland established, when there was a series of raids on saunas connected with the sex industry in Edinburgh. Members of the Scottish Parliament, women's 
groups, and the sauna owners voiced their concern about the raids on businesses which had, before the merger of Scotland's police forces, been tolerated as part of a harm reduction approach of the former local police force in its dealing with the sex trade in the city. According to the Convenor of the Scottish Parliament's Justice Committee, these raids provided 'quite a dramatic example of the fears that local policing-which seemed to be succeeding in a different way in a different place-was being overridden by a national attitude that came from the top'. This view was later endorsed by one of Police Scotland's most senior officers who, in a newspaper article under the headline 'Edinburgh sauna raids show police culture clash', observed:

The sauna raids in Edinburgh challenged a way of policing that had existed for a decade or more in terms of style and methods. The new policy pursued by Police Scotland challenged the approach that police had taken there which was about tolerance and harm minimization' (The Scotsman, 2014a).

These observations about the way in which local approaches to policing communities were being overridden by new national policies developed and implemented by the Chief Constable soon started playing into a broader narrative around police reform as critics sought to highlight the emergence of a policing environment characterized by a significant local democratic deficit, a strong focus on enforcement, and the emergence of a 'one size fits all' approach to policing for the whole of Scotland. As part of this narrative, a media and political discourse developed around what was dubbed the 'Strathclydification of policing' as commentators began to frame the creation of Police Scotland in terms of a 'takeover' by Strathclyde Police (by far the largest of the legacy forces) rather than a 'merger' of eight forces. This was largely attributed to the appointment of the Chief Constable of Strathclyde Police to the position of Chief Constable of Police Scotland and the subsequent deployment of policing methods and priorities 
that had been associated with the Strathclyde force. This included the introduction of a performance management system characterized by a strong focus on enforcement targets and proactive policing methods. Exemplifying this approach was the increasing use of the tactic of 'stop and search' across Scotland. In the nine months following the establishment of new force the number of recorded stops increased in more than two thirds of local authority areas across the country, in some places by over 400 percent, leading to heated political debate about the legitimacy of using these powers on such a large scale (see Murray and Harkin, 2016). Responding to these concerns, the new Scottish Police Authority undertook their own scrutiny of the issue. They highlighted the risks of using stop and search on such a large scale, including the potential to cause 'a loss of confidence within the community which could undermine the principle of policing by consent and damage the ability of the police to work in partnership with the community to tackle crime' (Scottish Police Authority, 2014: 4).

Other examples of local communities apparent powerlessness in the face of centralised decision-making included the decision by Police Scotland to either close or reduce the opening hours of public counters in local police stations. This was one of a rnage of measures to reduce costs to meet savings targets set by Scottish Government. Local councillors were not only unhappy about this decision but also by the lack of communication and consultation about this with the affected communities. A further example concerned the decision that firearms officers were to carry their weapons while on routine patrol rather than these being kept within a locked compartment in a police vehicle until they were needed. This caused particular concern in the northern area of Scotland which has the lowest recorded crime rates in the country and where the decision had been opposed by local councillors, the local MSP and local MP. The local authority took its concerns to the SPA which took the view that this was an operational matter for the chief constable and thus an area in which they could not intervene. This left councilors feeling that they were powerless to influence decisions taken at a national level. According to the deputy leader of the local council: 
It is also clear ... [the Chief Constable] is not willing to entertain the idea of regional variation of the standing authority ... contrary to the assurances that were given at the time the single police force was created. (Quoted in The Scotsman, 2014b).

The cumulative effect of these and other developments was a growing sense of a crisis of localism in relation to policing in Scotland, prompting the Scottish Government to call a Local Policing summit in 2015 at which they announced that there would be a review of police governance undertaken by the Chair of the Scottish Police Authority. A key focus of this review was to address the way in which local authorities did not feel sufficiently listened to regarding local policing and their concerns that they were unable to input into national policy issues that had local consequences (see too Henry, Malik, and Aitchison, 2016a and 2016b). As the Chair of SPA explained:

Local scrutiny bodies feel they do not have a sufficient role in developing local police plans and determining local policing policies. Similarly they have concerns regarding the ability to contribute to national policies. Even if consulted they do not believe their community concerns are being listened to sufficiently. ... Local commanders do not appear to have sufficient autonomy to adapt national policing requirements to community needs where appropriate.' (Scottish Police Authority, 2016)

\section{Engaging with the local experience of organizational change during police reform}

Although the political, policy and media discourse has focused on several high profile examples of the impact of centralized decision-making on local policing, there has been less attention paid to how the organizational changes brought about by reform have been perceived and experienced by local officers and local stakeholders and impacted on their assessment of whether of whether the three strategic aims 
for reform articulated by the Scottish Government have been realized at a local level. The remainder of this paper focuses on these aspects of local policing, drawing on data gathered during 2016 as part of a four year independent evaluation of police reform commissioned by the Scottish Government (see SIPR et al, 2016 and 2017). Four case study areas (each comprising one or two electoral wards) were selected to include both urban and rural communities, areas with high and low crime rates, and with levels of greater and lesser deprivation. In each case study area, qualitative interviews and focus groups were used to capture the experiences and perspectives of local police officers $(n=25)$ drawn from local policing teams (comprising constables, sergeants and inspectors). In addition interviews were carried out with locally elected councillors and local authority staff $(n=17)$, local third sector organisations and community council members $(n=15)$ and members of the public via 8 focus groups ( 2 per area with $8-10$ participants in each). In each area, one general public focus group took place with those aged 55 and over and another with those aged under 55. All focus groups contained both men and women, a mix of ages (within the parameters set for the group), and of unemployed, employed, retired people and students. The majority of participants had had some form of contact with the police, from attending a local public meeting about policing to reporting a crime, but they were not recruited on the basis of their contact. With the consent of participants, the interviews were digitally recorded and transcribed verbatim. In the following sections we examine the data in relation to the three strategic aims of reform and the wider changes in the working environments of police officers.

\section{Protecting and improving local police services?}

Since the start of reform in 2013 Police Scotland has focused on rationalising service provision by ending the duplication of support services present in the eight legacy forces while maintaining routine operational delivery. There is evidence of progress in achieving this in terms of reduced duplication of 
'back office' functions such as Human Resources and Finance, a reduction in the number of senior police officers and civilian staff at management levels, and a move to fewer but larger control rooms. From the perspective of local officers, however, their experience of these and other changes was a sense that local resources were increasingly stretched in relation to levels of demand. In all four case study areas local officers spoke of the cumulative consequences of national level decisions which were impacting on the level of available resources locally. These national decision related to the 3 ' $R$ 's of redeployment of officers to specialist teams, reductions in civilian staff, and restructuring of resource provision and geographical responsibilities. In relation to redeployment, for example, the evidence gathered for the case studies is that the creation of specialist teams has resulted in some officers being redeployed away from local areas and then not being replaced:

'The biggest thing for us is staff, since Police Scotland came along are the specialist units up here that we never used to have before, taking frontline officers and putting them in there, and never ever replaced them on shift' (Local police officer)

The processes of reducing duplication in support services brought about by reform has also led to reductions in the numbers of civilian staff across Police Scotland. As a result, some of the responsibilities, for which civilian staff had previously provided assistance, were now more commonly carried out by police officers, such as dealing with public inquiries at the front desk in police stations, typing up notes, and running checks on databases. The restructuring of resources as part of the process of reducing duplication had also impacted on local policing. Since reform, officers spoke of having to cover wider geographical areas than previously, partly as a result of the closures of other local police stations. This has had a particular impact in relation to accessing custody suites. In the case study areas local custody suites had been closed due to a lack of resources and were now located further away from 
the local police stations where officers worked than before reform, increasing travel times with detainees and leading to longer periods of absence from local areas. The public, community organisations and councillors in the case study areas were aware of many of these changes and the potentially negative consequences for community engagement and levels of local knowledge. Their concerns coalesced around a number of issues including the larger police beat areas, a perception that they no longer knew their local officers and that these officers rarely attended community events, more limited access to officers at the local station, and the presence of officers from outside the local area:

I'm not saying there's none but it's more and more...not locals. So they're not aware of the area, they're not aware of where there is trouble'. (Public focus group)

\section{Creating more equal local access to specialist police support and national capacity?}

One of the major aims of police reform has been to end the so-called postcode lottery of local access to specialist expertise and resources that characterised the former arrangements based on eight forces. Since reform there are new processes in place to access resources via a national Operational Support Division (which includes air support, the marine unit, dogs and horses, and firearms) and a national Specialist Crime Division (SCD). There are also Major Investigation Teams (MITs) based regionally covering the North, East and West areas of Scotland which focus on homicides and other serious crime. Viewed from the perspective of local policing teams many officers felt they could now draw upon resources and expertise which prior to reform they would have had limited or no access to. This was a view particularly voiced by those working outside the boundaries of the legacy Strathclyde Police force area who now felt that the visibility and availability of Major Investigation Teams and air support in particular had increased. Local officers also recognised the value of being able to access specialist 
capability when there were major incidents in ways which allowed local policing capacity to remain focused on delivering a local service.

Nevertheless, there remained aspects of the process of accessing specialist expertise which local officers felt could be improved. The perception among some local officers who were now making use of a range of new processes and structures for accessing specialist support was that they were quite bureaucratic, particularly when compared with the more informal system for arranging specialist support that existed prior to reform. There was also a perception among local officers that specialist teams found it more difficult to respond to spontaneous as opposed to pre-planned incidents and that there could be delays in the deployment of specialists if they were already committed to activity in another area. In particular some local officers expressed concerns about the capacity of some specialist teams including the dog and road policing units and scenes of crime officers to meet all the demands that were placed on them and the competition that now exists between regions for resources.

More generally, as a model of service delivery, the division between specialists operating as a regional or national resource and generalists working at a local level while having important benefits in terms of efficiency and effectiveness, brought with it a range of concerns for local officers. The centralised management of specialist teams and their physical location at a distance from local policing teams meant some local officers reported that they only had limited knowledge about the role, purpose and remit of some specialist teams. The issue here, however was not just the geographical distances specialist teaams now need to travel when they are deployed to tackle local problmes, but the limited local knolwedge they bring:

'when we want a specialist resource, it's got to come 50 miles. You know? It's got to travel 50 miles to get here, to an area they don't know, to people they don't understand, you know? It just doesn't work. (Police officer-local policing team). 
Local officers also expressed concern that the centralisation of specialist support teams was presenting a barrier to local career progression and that their opportunities to learn new skills were limited, as investigations of a serious nature were now passed immediately from local police teams to specialist teams. Similarly, local officers perceived a potential problem in the future if those who remain in specialist teams lose the skills required to operate as a generalist in a local policing role, fostering the development of an 'us and them' culture between local officers and specialist teams (see too Fyfe, 2018).

\section{Strengthening the connections between police and local communities?}

Across all four case study areas, the public and local councillors were generally very positive about their interactions with their local policing teams. The public valued the activities that the police undertook to engage with the local community by visiting local schools, attending local events and participating in community council meetings. However, the public perception was that police engagement in these areas had decreased since reform and local officers also voiced concerns about their capacity to maintain community engagement activities. This was seen partly as a product of taking on additional local responsibilities, changing shift patterns and having to work across wider geographical areas since reform, but also reflected a more general perception that at a national level the expectation from chief officers at a national level was for them to be more focused on response and enforcement rather than engagement. For local officers this experience resulted in being less well-known in local communities which reduced the opportunities for gathering local intelligence:

'It's sometimes hard, as much as we are community officers we don't always get to be community officers a lot of the time because the response police are quite often so small in numbers that a lot of the time we are missing community meetings. We don't get to...pop into schools - we should be 
visiting the schools every couple of weeks. We don't get to do it a lot of the time due to all the other factors - covering front bar, police officers covering prisoner watches, just doing different things that a lot of the time it does feel like you're not a police officer.' (Local police officer)

These concerns were underlined by local councillors who described police attendance at community council meetings as being less consistent since reform. Local officers also felt that the decision to shut some police stations or limit their opening hours as a way of dealing with budgetary pressures had made it more difficult for the public to contact the local police. The public, councillors, and community organisations were also aware of station closures and changes in the opening hours of the police stations in their local area and had concerns about the signal this sent to the local community about the accessibility of the local police and the ability to report crime and share information.

Following the introduction of the single non-emergency number (101) for Scotland, the limited opportunity for direct telephone communication between the public and their local police officers has also led to some officers voicing concerns that the public were now less likely to report low level incidents or suspicious behaviour. Consequently, local officers indicated that they were receiving less information from the community about what was happening in their local area and that some types of low level crimes might be going unreported and therefore not reflected in police crime figures. This concern was shared by the public, councillors, council staff and community organisations who mentioned delays in responses to 101 calls and not being able to speak to someone locally. This was seen as a particular issue in rural areas where community organisations also expressed concerns that the public were less likely to report crimes and provide intelligence through 101 than if they could speak directly to a local officer: 
'...And then they'll tell you something like this guy is selling drugs, or this guy is doing that or whatever. And uh...they say ah yes this is 2 weeks ago but I just can't get hold of the front counter staff to let the police know and I don't bother with 101...' (Local police officer)

'So it's just you've lost the kind of...I think the police have lost a source of information you know they're not in...they're not in touch with the grassroots if you like...the people, because they're behind call centres, or...you know?' (Local community organisation)

The introduction of the 101 number was also perceived to be problematic by members of the public and some local officers because of their concerns about the level of local knowledge held by contact centre staff. The public in rural areas felt that the 101 number was being covered by people who were from outside the local area and who did not know the locality, a concern shared by some officers who felt that knowledge of the local areas was especially crucial to help direct them to remote locations, for example in relation to road accidents.

\section{Discussion: the local experience of organisational change in a 'frontline' organisation}

The perceptions of local police officers regarding their experience of reform in the context of the three strategic objectives set by the Scottish Government at the outset of the reform process indicates the scale of the challenge involved in bringing about organisational change in policing. Although drawn from four very different areas of Scotland, the local case study evidence presents a remarkably consistent picture. From the perspective of local police officers, routine delivery of local services is operating with diminishing resources and that work to strengthen connections with communities was often hampered by other organisational pressures. Many of the challenges around local resourcing appeared to reflect the cumulative consequences of a series of separate decisions related to the staffing of specialist units, 
reductions in civilian support, increased areas of geographical responsibility and the consolidation of some functions in a limited number of locations. Community officers in particular felt they didn't have as much time to commit to engagement work as they would have liked and that their primary role in some areas was simply to support response officers. Local officers were, however, generally, more positive about accessing specialist expertise but had concerns about equity of access and some of the potential longer term consequences around deskilling and career development.

Standing back from officers percpetions in relaiton to the aims of reform, it was also possible to discern that much of what local officers have experienced is consistent with the wider literature on organisational change and change in frontline organisations (see Behn, 1995). This focuses attention on how effective internal communication, credible support from senior staff, and clarity around the 'big picture' must all be in place to facilitate change (Tops and Spelier, 2013). In relation to internal communication and support from senior staff, for example, many of the constables interviewed in the case study areas felt that they now had less access to and interaction with more senior officers than they did before reform. This was partly explained by changes to the physical location of supervision and management teams which were often at some distance from local stations. In terms of supervision, many local officers felt that the increase in the number of officers that Sergeants now supervise meant there was less direct supervision and some officers in rural areas mentioned that supervisors can be based in a different location to some of the officers they supervise, increasing the challenges around effective communication. Indeed, one consequence was that local officers felt that the primary form of communication between senior and lower ranking officers was now by email. Many officers also discussed communication around the use of targets within Police Scotland and although there was widespread awareness that the appointment of a new Chief Constable in 2016 had led to a change of 
approach in this area, some local officers interviewed still perceived an organisational pressure to deliver targets:

'...they were quite clear that there were no targets for operational cops however, divisional commanders were being pressured into providing answers to...senior members of the Executive as to why their stop/search figures were down or why their assault rate was up, the commission rate, or why the volume of serious assaults were up.' (Local police officer)

The significance of targets was also about how these communicated a message to local officers about the 'big picture' in terms of what the organisation viewed as important and many of the targets were seen as having an enforcement rather than engagement focus:

'So we're still kind of getting things there, a lot of the time it is extra pressure on us because we could be out and we're community officers, so we should be out engaging but you never ever get a well done you've went around and you've visited your schools, and you've visited the shops, you never ever get that. It's well why have you not got a return, why have you not got somebody out smoking drugs, or out drinking, why have you not got anything so I think that definitely is still a pressure of you need to come back with something and there's never a...very little is there a well done you!' (Local police officer)

Linked to this was a frustration that much of that communication focused on the 'what' and 'how' of changes but there was a clear desire to hear more from senior officers about the 'big picture' in terms of the reasons why changes were being introduced:

'Why can't our Inspectors and our Chief Inspectors come in and engage with us, and actually explain to us the reasoning behind why they want these things done?' (Local police officer) 
These concerns also fed into wider issues about career development and morale within the new organisation. Some officers felt that the creation of a single national police force had increased their career opportunities compared with legacy force arrangements, as they did not have to apply to a new police force to access a wider range of opportunities, although they recognised that there may still be a need to relocate to join different specialist teams. Other officers felt that opportunities for promotion had been reduced. They perceived Police Scotland as moving to limit the overall number of supervisory ranks, resulting in officers seeing themselves waiting many years before they were able to get promoted. There was also a view that younger officers may leave the service if they weren't promoted especially as other benefits, such as pensions, have also been cut back.

These frustrations around career development when combined with concerns about the impact of having reduced resources, or being asked to do more with the same resources; the increase in paperwork and the subsequent impact on officers' workloads; the lack of paid overtime and limited flexibility in working patterns; the reduction in pension benefits; and a lack of positive feedback from senior officers contributing to a percpetion of low morale within the organisaiton:

'...think everyone's suffering from low morale since... since it (Police Scotland) came in. I've never seen anything like it. When I joined, it was...it was quite up... you know, it was very upbeat, you know? It was a great job to get into, you know?' (Local police officer)

The amount of change officers are having to cope with was also seen as having a negative impact on morale:

'And I think a lot $o^{\prime}$ cops are upset because they are demoralised because things are changing all the time. It may be a change in domestic procedures, stop/search procedures, roads policing procedure... er ... and every couple $o^{\prime}$ days there's a change. The laws are not changing. It's just how we deal wi' 
them. Can we no just slow down and have a proper think? ... er ... make sure things are working first and then, and, if it's not working, change it? - Instead o' just saying, "Oh, quick ... quick ... Right. Oh, we'll change it now"' (Local police officer)

These qualitative insights confirm the picture that emerged in 2015 from a large scale opinion survey carried out by the Scottish Police Authority and Police Scotland which also highlighted significant areas of workforce dissatisfaction in relation to information and communication, feedback, training, career development and well-being (Axiom, 2015). Only a third of police officers who responded to the survey felt they were fully or well-informed about what was happening in Police Scotland and only $12 \%$ thought that the reasons for change were well communicated to them; and less than a quarter felt they had the resources they needed to do their job properly. In relation to the 'big picture' less than a quarter of officers felt they had appropriate information on what Police Scotland wants to achieve.

While there were some differences in perceptions between more experienced officers compared with newer officers who had not worked under the previous systems, there were shared concerns about the consequences of low morale for retention and levels of stress. Officers felt that the changes in working conditions, such as the lack of overtime, reduced pension and increased workloads, had led to many experienced officers leaving the service. The police, it was argued, was no longer seen as a career for life and officers may now only work as an officer for a few years and then pursue a different career. Officers also reported that they found their job more stressful, in part due to the experience of increased workloads and the addition of new procedures which created additional administrative tasks. Officers felt that sickness levels had increased since reform and also that officer's physical and mental wellbeing were being affected by the changes that had occurred since reform:

'And I just think everybody's getting stressed out, because the workloads are getting bigger. You're no getting the time to do the enquiries, yet obviously you've got court dates to meet, you've got 
deadlines to meet for getting, you know, like reports done and stuff, and you're just .. You've just no got the time because you've no got the manpower to deal with the work that's coming in! to get stuff done' (Local police officer)

\section{Conclusions: lessons for the future?}

Local policing has emerged as one of the most contentious areas of police reform in Scotland. Despite a high level commitment to local policing set out in the Scottish Government's legislation and strategic aims for reform, the implementation of new policing arrangements has proved highly problematic at a local level. Many of these concerns stemmed from what was seen as a top-down, 'one size fits all' approach to the policing of Scotland that appeared to be informed by priorities and tactics which has prevailed in the former Strathclyde police area. A number of high profile issues including the wide spread use of stop and search and decisions about the arming of officers played into this narrative and also served to highlight the relative powerlessness of local communities to influence police decisionmaking. In addition, however, the more routine aspects of local policing have also been under pressure as a result of the organizational changes brought about by reform. Focusing on the perceptions of local police officers in 4 communities across Scotland, this paper has highlighted their concerns in relation to service delivery, accessing specialist support, and the capacity for community engagement. A consistent message emerges across all the localities of a sense of diminishing resources in relation to an increasing workload; challenges around navigating new organizational boundaries between specialists and local policing teams; and a prioritization of enforcement rather than engagement focused activities. It is important to acknowledge that these difficulties are not unique to police reform in Scotland.

Placed in a comparative perspective (Fyfe, Terpstra and Tops, 2013 and this Special Issue) there is clear evidence that progress with large scale organisational police reforms in other jurisdictions has occurred 
more slowly and proved more difficult than expected. Often the implementation process has been more complex and time-consuming than predicted and gaps have emerged between what managers and employees expect from reform. In many countries, the focus in the initial stages of implementation appears to have largely been on central management and reinforcing national structures, with the result that less attention has been given to engaging with employees in the new organisation. There have also been tensions between needs of national and local levels of the new organisations: a focus on establishing consistency at a national level has taken priority over local flexibility and autonomy.

It is also important to recognise that some of the areas of concern identified in this paper have now been highlighted in recent policy statements. The Scottish Government's (2016) Strategic Police Priorities for Scotland, for example, identifies localism as a key issue and refers to being able to 'Ensure that the needs of local communities are understood and reflected in the planning and delivery of policing at a local and national level'. Localism also means communities having a strong voice in policing decisions that affect them locally and the police being responsive to community concerns, issues addressed in the Scottish Police Authority's (2016) Review of Governance in Policing. These commitments dovetail with the Strategic Objectives set out in Policing 2026: Our 10 Year Strategy for Policing in Scotland produced jointly by Police Scotland and the Scottish Police Authority. These include 'Improving public contact, engagement and service', strengthening 'effective partnerships' and investing in the 'use of information and technology' (Police Scotland and Scottish Police Authority, 2016).

Finally, there are two important lessons for future policy and practice that emerge from this analysis of local policing during a period of reform. First, there needs to be careful modelling of the interdependencies and cumulative consequences of decisions taken centrally for local service delivery. Many of the more challenging issues faced locally by policing are rarely the result of a single change in 
policy or practice. Rather they are the unintended consequences of a whole series of individual decisions which may make sense organisationally for one area of business but which come together in specific ways in local environments. This means there also needs to be significant organisational awareness of the tensions between the representations of reform in policy and strategy documents, and the experience of reform in the day-to-day local working environments of those in 'frontline' roles. This means recognising that locally staff will have a range of anxieties about reform, from its immediate consequences for 'getting the job done' through to its longer term impacts on their careers, which need to be addressed. This feeds into a second lesson: the need for, meaningful, authentic and open communication within an organisation throughout the reform process. There has to be a commitment at a senior level to explaining not just the 'what' and 'how' of organisational change but also the 'why'. This should also open up a space for dialogue so that staff at all levels of an organisation feel engaged with the decision-making process and that the scope to influence change is dispersed through the organisation and not just concentrated in the hands of a few senior staff. Previous research on police reform has consistently highlighted that there are 'few efforts to give officers a collective, deliberative voice in how policing is carried out' (Skansky and Marks, 2008, p.2) yet has emphasised that rank-andfile officers can also be 'change agents' in reform programmes (Toch, 2008) and that their involvement can enhance morale, commitment and make for better decisions. If police reform in Scotland and elsewhere is to deliver long term benefits, those working in local roles need to be included in the process to improve service delivery, shown the 'bigger picture' and have the opportunity to use their 'street 'or 'craft' knowledge to provide more nuanced answers to some of the complex questions reform poses.

\section{References}


Axiom (2015) Report for Scottish Police Authority/Police Scotland Opinion Survey 2015, Glasgow: Axiom Consultancy.

Bayley, D. (2008) Police Reform: Who done it?, Policing and Society, 18(1), 7-17.

Fyfe N R (2014) A different and divergent trajectory? Reforming the structure, governance and narrative of policing in Scotland, in Brown, J. (Ed), The Future of Policing. London: Routledge, pp. 493-506.

Fyfe, N.R. (2016) Policing Scotland post reform: towards a shifting 'culture of control' and a new politics of policing? In Croall, H., Mooney G. and Munro (eds) Crime, Justice and Society in Scotland, London: Routledge, 167-181.

Fyfe, N.R. The changing ecology and equity of policing: reconfiguring organisational boundaries in an era of police reform. In Fyfe, N., Gundhus, H. and Ronn, K. (eds) Moral Issues in Intelligence-Led Policing, London: Routledge.

Fyfe N R and Scott KB (2013) In search of sustainable policing? Creating a national police force in Scotland. In: Fyfe NR, Terpstra J and Tops P (eds) (2013) Centralizing forces? Comparative Perspectives on Contemporary Police Reform in Northern and Western Europe. The Hague: Eleven International Publishing, pp. 119-135.

Fyfe N R, Terpstra J and Tops P (eds) (2013) Centralizing forces? Comparative Perspectives on Contemporary Police Reform in Northern and Western Europe. The Hague: Eleven International Publishing.

Hail, Y. (2017) Local Policing in Transition: examining the impacts and implications of police reform in Scotland. Unpublished PhD thesis, University of Dundee.

Henry, A., Malik, A. and Aitchison, A. (2016a) Partners in Scrutiny Briefing Paper 1: Mapping Local Scrutiny Arrangements in Scotland. Scottish Institute for Policing Research Briefing Paper 15 http://www.sipr.ac.uk/downloads/Briefing15.pdf (accessed 16 August 2017). 
Henry, A., Malik, A. and Aitchison, A. (2016b) Partners in Scrutiny Briefing Paper 2: Three Local Scrutiny Committees. Scottish Institute for Policing Research Briefing Paper 16 http://www.sipr.ac.uk/downloads/Briefing16.pdf (accessed 16 August 2017)

Murray, K. and Harkin, D. (2016) Policing in cool and hot climates: legitimacy, power and the rise and fall of mass top and search in Scotland, British Journal of Criminology. Accessed via online first: https://doi.org/10.1093/bjc/azw007_(30th June 2017)

Police Scotland and Scottish Police Authority (2017) Policing 2026: Our 10 year strategy for policing in Scotland http://www.scotland.police.uk/assets/pdf/138327/386688/policing-2026strategy.pdf?link=landing1 (accessed 15 $5^{\text {th }}$ June 2017) The Scotsman (2014a) 'Edinburgh sauna raids show police culture clash' 30

The Scotsman (2014b) 'No discussion' on Highland armed police decision. http://www.scotsman.com/news/scotland/top-stories/no-discussion-on-highland-armed-policedecision-1-3470327 (accessed 15th June 2017)

Scottish Government (2011a) Renewing Scotland: Scotland's Programme for Government 2011-12. Edinburgh: Scottish Government. Scottish Government (2011b) Research Support for a Consultation on the Future of Policing in Scotland. Edinburgh: Scottish Government.

Scottish Government (2016) Strategic Police Priorities for Scotland http://www.gov.scot/Resource/0050/00506835.pdf_(accessed 15th June 2017) 
Scottish Police Authority (2014) Scrutiny Review - Police Scotland's stop and search policy and practice, Glasgow: Scottish Police Authority.

Scottish Police Authority (2016) Review of Governance in Policing

http://www.spa.police.uk/assets/128635/337350/337362 (accessed 15th June 2017)

SIPR (Scottish Institute for Policing Research), ScotCen and What Works Scotland (2016) Police and Fire Reform Evaluation: Year 1 Summary Report. Edinburgh: Scottish Government.

SIPR (Scottish Institute for Policing Research), ScotCen and What Works Scotland (2017) Police and Fire Reform Evaluation: Year 2 Summary Report. Edinburgh: Scottish Government.

Skansky, D. and Marks, M. (2008), The role of the rank-and-file in police reform, Policing and Society, 18(1), 1-6.

Terpstra, J. and Fyfe, N. (2015) 'Mind the gap: local policing and police reform in the Netherlands and Scotland', Criminology and Criminal Justice, 15(5), 527-544.

Toch, Police officers as change agents, Policing and Society, 18(1), 60-71. 